\title{
BENJAMIN ZEPHANIAH: CONTEMPORARY VOICE OF RESISTANCE IN BLACK BRITAIN
}

\section{SUSAN SATHYADAS}

M. Phil. Scholar, University of Kerala, India

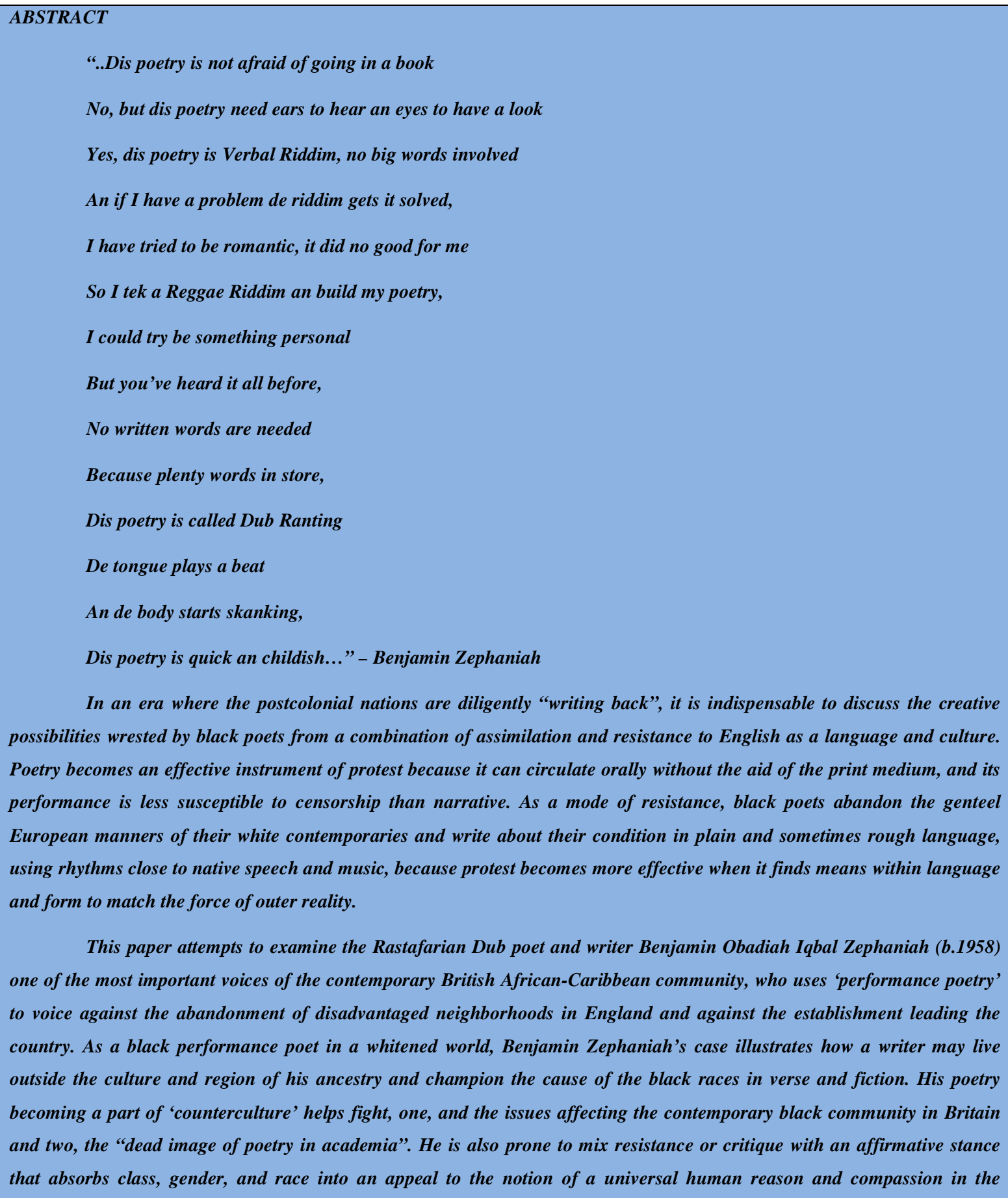




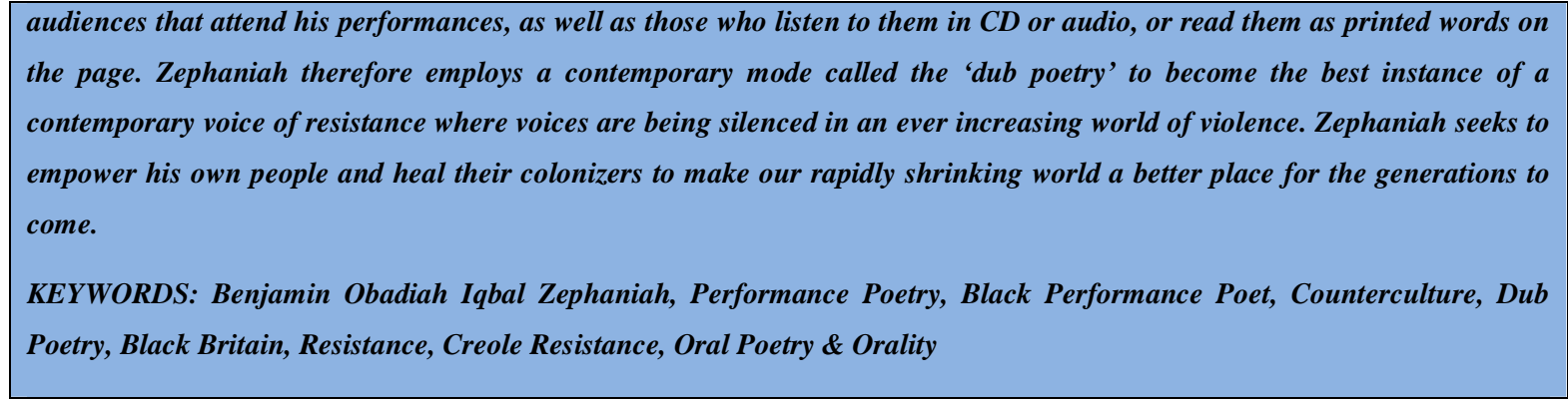

Received: Jun 10, 2017; Accepted: Jun 25, 2017; Published: Jul 12, 2017; Paper Id: IJELAUG20179

\section{INTRODUCTION}

In the Caribbean, 'creolization' proved a more viable poetic strategy to resist the norms of Standard English. Through Creoles, orality was able to resist, infiltrate, subvert and modify the norms of Standard English. It challenged the assumption that in creating works of art, the standard form of a European language was the only way to access either the local or the universal. For some writers like John Figueroa, Standard English remains the 'Prosperian element': "Watch dis pentameter ting, man/Dat is white people play!/[...]/Like metronome, yu'd say,/But a black bwoy should play/without dem mechanical aids/ Full of rydhm like all true spades." (Brathwaite 1984:39) "I find that the only way I can express myself in English is by abusing the English language in such a way that it says what I want it to say" remarks the Zimbabwean poet Dambudzo Marechera.

'Creole resistance' later termed as 'performance poetry/dub poetry', focused on breaking down the iambic rhythm, displacing it with the intonation and rhythms of the calypso. Dub poetry usually taken to refer to a particular type of "performance poetry", is a brand of oral poetry performed to the accompaniment of reggae music. The term "dub poetry" is thought to have been invented by the Jamaican poet Oku Onuora to describe a form of oral art that had been developing in Jamaica since the early 1970's. Musicality is built into Dub poems, yet, Dub Poets generally perform without backing music, delivering chanted speech with pronounced rhythmic accentuation and dramatic stylization of gesture. Dub poetry is predominantly concerned with politics and social justice, commonly voiced through a commentary on current events. This contemporary vernacular form is a genuine expression of Jamaican culture as well as the best expression of resistance to marginalization, racism, and sexism.

Christian Habekost, an expert on the Anglo-Caribbean performance culture, identifies several features that play a prominent role in the per formative aspect of dub poetry: 'rhythm, rhyming patterns, alliteration, repetition, onomatopoeia and a highly individuated performance style that combines musicality with dramatic flair' (1993:91-8). In such writing, the poem is not the experience of an isolated individual reading a book; rather it sounds shared as utterances with an audience who participates in the experience of poetry as community. "I'm no poet/no poet/ I am just a voice/ I echo de people's/thought/laughter/cry/sigh" declares Oku Onuora, in "No Poet” (Glaser and Pausch 1994:5). Performance poetry therefore dismantles the traditional definitions of poetry where words come off the page and move to a beat learnt from music. It gives anger and suffering an opportunity to be enacted as a ritual of popular culture as well as ameliorates the condition of those who feel uprooted in time and displaced space. It mobilizes verbal energy and anguish into an expressive force for social change.

Rastafarian Dub poet and writer Benjamin Obadiah Iqbal Zephaniah (b.1958) are the most important voices of the 
contemporary British African-Caribbean community who uses 'performance poetry'/ 'dub poetry' to voice against the abandonment of disadvantaged black neighborhoods in England and against the establishment leading the country. As a Jamaican black performance poet in a whitened world, Benjamin Zephaniah's case illustrates how a writer may live outside the culture and region of his ancestry and champion the cause of the black races in verse and fiction. For his outstanding work in the field of literature Zephaniah was put forward for the post of "Oxford Professor of Poetry" in 1989 and "UK Poet Laureate" in 1999, and was also offered an OBE in 2003, which he declined. He states that he "lives in two places, Britain and the world", and his collections highlight domestic issues from institutional racism (Too Black, Too Strong, 2001) and the murder of Stephen Lawrence to conditions in war-torn Bosnia, the plight of occupied Palestine (Rasta Time in Palestine, 1990) and global environmental issues ( Talking Turkeys, 1994). In 2011, Zephaniah appeared in literature to support changing the British electoral system from first-past-the-post to alternative vote for electing Members of Parliament to the House of Commons in the Alternative Vote referendum. Zephaniah's poetry is mostly inspired by political causes and speaks in favor of a British Republic and the dis-establishment of the crown. In one of his poems "Naked" which appears in Too Black Too Strong, he out rightly says:

Dis is me. I hate dis government as much as I

hated the one before it and I have reason

to believe that I will hate the one to come.

[...]

Dis is me, squeeze me. Let me free me.

I have come to realize that what you can do for me

I can do much better for me.

Let me do for my loved ones what you will not do for them

I want to hold the hands of my loved ones

(Those who have no one to vote for)

and cause a rumble in dis black universe.

Causing a rumble in the "black universe", Zephaniah has buckled himself to the task of revolutionary transformation to teach his audience that it is the lowly and inconspicuous who will blast history apart. His poetry speaks of and for the experience of the blacks and the number of issues which plague the black community- unemployment, prostitution, crime, racism, denial of human rights and so on.

Zephaniah's poetry becoming a part of 'counterculture' helps fight: one, the issues affecting the contemporary black community in Britain and two, the "dead image of poetry in academia”. In contemporary Britain, Zephaniah's poetry could be heard on the demonstrations, at youth gatherings, outside police stations, and on the dance floor. It was once said of him that he was Britain's most filmed, photographed, and identifiable poet, this was because of his ability to perform on stage, but most of all on television, bringing Dub Poetry straight into British living rooms. Zephaniah's mission is to "take poetry everywhere", as he hates the dead image that academia and the establishment has given poetry and proclaims that he is out to popularize poetry by reaching people who do not read books, while those who are keen on books can now witness 
a book coming to life on the stage. His poetry is political, musical, radical, relevant and on TV. His poem "Riddim Having a Word" (Too Black Too Strong) is a best instance of a thought provoking poem which is political, musical, radical as well as relevant:

\author{
I have learnt that equality \\ May not mean freedom, \\ and freedom \\ May not mean liberation, \\ you can vote my friend \\ and have no democracy. \\ Being together dear neighbor \\ May not mean unity, \\ your oppressors may give you chances
}

But no opportunities,

and the state that you are in

May have its state security

Yet you may be stateless

Without protection.

This poem suggests a sense of political engagement and conveys a strong disenchantment with the current order of society. He is also prone to mix resistance or critique with an affirmative stance that absorbs class, gender, and race into an appeal to the notion of a universal human reason and compassion in the audiences that attend his performances, as well as those who listen to them in $\mathrm{CD}$ or audio, or read them as printed words on the page. A typical Zephaniah poem maintains a reggae rhythm and a regular iambic mostly tetrameter line-beat. His lines usually begin with a trochee and the poems sustain a rhyme scheme locked to a few rhyming sounds, same word sounds or word endings, like the ballad, the sestina or villanelle. He has in fact brought poetry in performance closer to 'ska', the native sound at the yard way of the Cultural Revolution that would lead eventually to Bob Marley, reggae and "The Harder They Come" (Jimmy Cliff). His ability to break language down to its bare elements and use it with a musicality and rhythmic propulsion that does away with many conventions of syntax is remarkable. Zephaniah being out of step with the current artistic culture prevalent in Britain today challenges the conventional English poets to decipher the new poetical language in his poem "Translate"

(Too Black Too Strong):

Who will translate

Dis stuff?

Who can decipher

De dread chant 
Dat cum fram

De body

An soul Dubwise?

$[\ldots]$

Sometimes I Wanda

Who will translate

Dis

Fe de English?

His style of writing reflects his Jamaican English accent where he spells words like 'the' in the same way he pronounces them for example, 'de'. Such poetry does more than allude to performance: it jumps off the page, the printed word asking to be heard as sound and pulse. Broken syntax doubles other kinds of breakdown: between thought and feeling, feeling and word, word and sense, sense and memory. There is always a beat or a bass line going on at the back of his head with words. Zephaniah's poetry dramatizes the predicament of a society whose assimilation into a rapidly globalizing modernity is marked by multiple forms of resistance. His poetry reveals a deeply ambivalent relation to the contemporary culture of London and the tradition of African poetry.

Resistance to racial discrimination remains the all-consuming theme of black poetry. Zephaniah, a leading figure and spokesperson in the fight against racism, rebels against the inert weight of racism and is strongly determined to write about the circumstances of black people living in Britain. In his remarkable work Too Black Too Strong (2001) he says, "I just feel a sense of urgency and I may not be right but I feel that (my) poetry has a purpose, well many purposes. I feel concerned that in the country of my birth my rights are ignored. In this multicultural, multiracial country, its prisons, its courts, even its hospitals don't recognize my religion (Rastafarianism) or cultural heritage." His poem "Three Black Males" indicates the overt racial discrimination or the color prejudice of the white society which mercilessly link blacks with all sorts of crimes and gangsterism in Britain.

Three black males get arrested

When they said they seek two whites,

Dis poet said that's expected

For we have no human rights,

We die in their police stations

We do nothing to get caught

We are only in white nations

When we win them gold in sports.

His poetry opens our mind to many things but above all seeks to empower his own people and heal their colonizers to make this rapidly shrinking world a better place for the generations to come. He poses challenges to the social 
order through performance poetry and is not afraid to write about the real world where there are bullies, guns, racism and war. He says in one of his poems: "I pay tax; they force me to pay for my oppression."("Naked") The depth of his writing comes from sometimes hard experience of life on the streets of Jamaica, Birmingham and London. His experiences inspired his poem "No Problem" where he says:

I am not de problem

But I bare de brunt

Of silly playground taunts

An racist stunts,

I am not de problem

I am a born academic

But dey got me on de run

Now I am branded athletic,

I am not de problem

If yu give I a chance

I can teach you of Timbuktu

I can do more Dan dance,

I am not de problem

I greet you wid a smile

Yu put me in a pigeon hole

But I a versatile.

The bruised language becomes in itself a new expressive device. In this poem, Benjamin Zephaniah talks about his life in England and shows that even from a young age when he was still at school he was racially abused and that people ridiculed him because of his race. "Silly playground taunts, an racist stunts" suggests that he was not welcome in the society in which he lived. His poetry is therefore a constant reminder for the black community of their plight to gain freedom. The messages which he conveys through his poems are not just religious, personal or political ideas, but global problems for all. This is not just about the struggle of the black people alone, but of all who are oppressed. This way his poetry speaks to the masses and his voice becomes the voice of the voiceless poor and the downtrodden.

His poems are successful social commentaries and act as a vehicle to focus on racial intolerance. One such example is his poem "Knowing Me" from Too Black Too Strong

As I drive on poetic missions

On roads past midnight

I am regularly stopped by officers of the law 
Who ask me to identify myself.

At times like these I always look into the mirror

Point

And politely assure them that

What I see is me.

I don't have an identity crisis.

This poem presents the inhuman treatment of the British officers of law towards a black individual in an ethnically and culturally plural Britain. And quite unlike other post colonial writers whose creativity is triggered by identity crisis and diasporic consciousness, Zephaniah declares that he does not have an identity crisis.

Even when identifying with the struggles of day to day life of black Britain, what characterizes all of Zephaniah's writing to date is its stress on the redemptive forces of love, laughter, and peace.

I am the type you are supposed to fear

Black and foreign

Big and dreadlocks

An uneducated grass eater.

I talk in tongues

I chant at night

I appear anywhere,

I sleep with lions

And when the moon gets me

I am a Wailer. (“Neighbors"”, Propaganda, 1996)

Set in a lighter tone, this poem informs the audience about the vexed issue of representation, and the need to validate the black British experience at a time, when it is being demonized more than ever. "Poeting all his life" Zephaniah has ended up being 'the people's poet'. Through his poetry, he has become an ambassador of his people and their religion. And what truly ought to be the life-song of Benjamin Zephaniah, a man born to fight is: "But I'll keep on fighting for the things I want/ though I know that when you're dead you can't/ But I'd rather be a free man in my grave/ than living as a puppet or a slave."(“The Harder they Come”).

\section{REFERENCES}

1. Lewis, William F. Soul Rebels: The Rastafari, Waveland Press, 1993.

2. McMurray, David. Rhythms of Resistance: Histories of Musical Opposition and Affirmation from Around the World, Vol.2, Cengage Learning, 2009. 
3. http://www.jamaicans.com/culture/rasta/reggae.shtml

4. Cooper, Carolyn. Noises in the Blood: Orality, Gender and the "Vulgar" Body of Jamaican Popular Culture, Duke University Press, 1995.

5. Hall, Stuart. "Cultural Identity and Diaspora". In Jonathan Rutherford (ed). Identity: Community, Culture, Difference. London: Lawrence and Wishart, 1998, 222-237.

6. Veal, Michael E. Dub: Songs capes and Shattered Songs in Jamaican Reggae. Middletown: Wesleyan University Press, 2007.

7. Patke, Rajeev S. Postcolonial Poetry in English. New York: Oxford University Press 2007.

8. Brathwaite, E. K. History of the Voice. London and Port of Spain: New Beacon Books, 1984.

9. Glaser, M. and Pausch, M. (Eds). Caribbean Writers: Between Orality and Writing. Amsterdam and Atlanta: Rodopi, 1994.

10. Habekost, C. Verbal Riddim: The Politics and Aesthetics of African-Caribbean Dub Poetry. Amsterdam and Atlanta: Rodopi, 1993.

11. Zephaniah, Benjamin. Too Black Too Strong. Blood axe Books Ltd, Northumberland, 2001.

12. http://www.benjaminzephaniah.com/content/185.php

13. Procter, James. (ed). Writing Black Britain 1948-1998: An Interdisciplinary Anthology. Manchester and New York: Manchester University Press, 2000. 